TULIP: Tulisan Ilmiah Pariwisata

ISSN: 2720-9873

Available Online at https://journal.umgo.ac.id/index.php/Tulip/index

Vol. 3, No. 1 Juni 2020

DOI: http://dx.doi.org/10.31314/tulip.3.1.12-18.2020

\title{
ANALISIS PERAN STAKEHOLDER DALAM PENGEMBANGAN DESTINASI WISATA
}

\section{Desrika Talib}

Program Studi Pariwisata, Universitas Muhammadiyah Gorontalo, Indonesia

Email; desrikatalib@umgo.ac.id

\begin{abstract}
Info Artikel Abstract:
Stakeholders are individuals or groups who are actively involved and have a Diterima: 20 much-needed role in the sustainability of development, including tourism. Mei 2020 The sustainability of tourism is very much determined by the active role of stakeholders in the development and management of tourist destinations.

Disetujui: 02 Various problems in the development of tourist destinations often occur, this Juni 2020 can be seen from several tourist destinations that used to be visited by tourists, but are no longer considered by tourists. This study aims to examine and analyze the role of stakeholders in the development of tourist destinations by means of literature review research. Based on the results of the literature analysis that the stakeholders include; 1) Primary stakeholders (primary), 2) Supporting stakeholders (secondary), 3) Key stakeholders.
\end{abstract}

Keywords: Role; Stakeholders; Development; Travel Destinations.
Abstrak:
Stakeholder adalah individu atau kelompok yang terlibat secara aktif dan memiliki peran yang sangat dibutuhkan dalam keberlanjutan suatu pembangunan termasuk pariwisata. Keberlanjutan pariwisata sangat ditentukan oleh peran aktif Stakeholder dalam pengembangan dan penegelolaan destinasi wisata. Berbagai masalah dalam pengembangan destinasi wisata sering terjadi, hal ini dapat dilihat dari beberapa destinasi wisata yang dulu ramai dikunjungi wisatawan, tetapi sekarang tidak lagi dilirik oleh wisatawan. Penelitian ini bertujuan mengkaji dan menganalisis peran Stakeholder dalam pengembangan destinasi wisata dengan jensi penelitian kajian pustaka. Berdasarkan hasil analaisis kepustakaan bahwa Stakeholder meliputi; 1) Stakeholder utama (primer), 2) Stakeholder penunjang (sekunder), 3) Stakeholder kunci.

Kata Kunci: Peran; Stakeholder; Pengembangan; Destinasi Wisata

\section{PENDAHULUAN}

Data Kemenetrian Pariwisata 2018 menunjukkan, sejak 2013 sektor pariwisata menempati posisi keempat setelah minyak dan gas bumi, batubara, serta kelapa sawit sebagai penghasil devisa negara. Hal ini membuktikan bahwa sector pariwisata di Indonesia merupakan sector ekonomi penting di Indonesia. Dalam rangka mendorong pertumbuhan pariwisata di Indonesia, 
pemerintah mengimplementasikan kebijakan Kawasan Ekonomi Khusus di sektor pariwisata.

Optimalaisasi pembangunan dan pengembangan pariwisata membutuhkan peran aktif stakeholder. Pemerintah dan masyarakat meruapakan dua unsur stakeholder dalam pelaksanaan pembagunan bidang pariwisata, dalam hal ini pemerintah memiliki peran yang sangat terbatas. Maka penggerak utama pembangunan dan pengembangan pariwisata adalah masayarakat. Hal ini sebagimana yang telah diamanatkan oleh Peraturan Pemerintah Nomor 50 Tahun 2011 tentang Rencana Pembangunan Induk Kepariwisataan Nasional Tahun 2010-2025 dalam peraturan ini diuraikan tentang kapasitas masyarakat dalam pengembangan pariwisata melalui peningkatan sumber daya masyarakat serta bagaimana meningkatkan kesadaran peran masyarakat. (PP No 50 Tahun 2011).

Melalui peraturan pemrintah dapat kita pahami bahwa pengembagan pariwisata juga harus dilaksanakan dengan adanya kerja sama antara organisasi pemerintah, pemerintah daerah, swasta dan masyarakat, sehingga dengan memberikan peran yang setara antara pemerintah dan masyarakat diharapkan dapat mempercepat pengembangan pariwisata.

Penelitian terkait peran stakeholder terhadap pengembagan pariwisata telah banyak dilakukan oleh para peneliti, salah satu di antaranya adalah penelitian yang berjudul
"Peran Dinas Pariwisata dalam Pengelolaan Wisata Minat Khusus di Kabupaten Ponorogo" oleh Nurul Rahmawati dkk. Dalam penelitian ini peneliti menjelaskan bahwa Dinas Pariwisata sendiri di pandangan kurang dalam pemberian pembinaan dan bantuan dalam pengelolaan wisata miant khusus itu sendiri. banyak desa atau pengelola wisata tidak memperoleh pelatihan, pembinaan dan bantuan yang tidak merata, mereka seperti tidak diperhatikan oleh Dinas Pariwisata (Rahmawati, Hilman and Triono, 2020).

Penelitian yang berjudul "Analisis Peran Stakeholder Dalam Pengembangan Wisata Talang Air Peninggalan Kolonial Belanda Di Kelurahan Pajaresuk Kabupaten Pringsewu" oleh Ni'mah A.Hidayah dkk. Dengan hasil penelitian menunjukkan bahwa pemangku kepentingan yang terlibat dalam pengembangan pariwisata Talang Air terdiri dari masyarakat, pemerintah, dan sektor swasta, dan pemangku kepentingan yang terlibat dalam pengembangan pariwisata Talang Air telah melakukan berbagai pengembangan baik pengembangan fisik maupun nonfisik. Kerjasama dan komunikasi yang ada antar pemangku kepentingan relatif baik sehingga mempercepat proses implementasi pengembangan pariwisata Talang Air (Hidayah et al., 2019).

$$
\text { Berdasarkan beberapa hasil }
$$

penelitian terhadulu, peneliti dalam penelitian ini memaparkan beberapa analisis kesimpulan terkait peran stakeholder dalam pengembangan destinasi wisata secara umum. 


\section{HASIL DAN PEMBAHASAN}

\section{Analisis Teoritis Stakeholder Pariwisata}

Stakeholder didefinisikan sebagai individu, kelompok atau organisasi yang memiliki kepentingan, terlibat, atau dipengaruhi (Secara positif maupun negatif) oleh kegiatan atau program pembangunan (Kristin and Salam, 2016). Berdasarkan definisi ini, maka dapat kita maknai bahwa Stakeholder adalah semua lapisan masyarakat yang memiliki kepentingan dan keterlibatan secatra langsung dengan suatu kegiatan atau program pembangunan, dan keterlibatan tersebut memberikan pengaruh terhadap suatu program pembagunan baik secara langsung maupun tidak. Dari pengertian ini dapat kita pastikan bahwa kegiatan pembagunan pariwisata sangat membutuhkan peran aktif dari seluruh stakeholder.

Bebrapa kajian terkait peran stakeholder terhadap pengembagan destinasi wisata, peneliti menemukan adanya pembagian stakeholder yang dikelompokkan atas tiga kelompok (Handayani and Warsono, 2017), yaitu :

1. Stakeholder utama (Primer)

Stakeholder primer merupakan stakeholder yang terkena dampak secara langsung baik dampak positif maupun dampak negatif dari suatu rencana serta mempunyai kaitan kepentingan langsung dengan kegiatan tersebut. Stakeholders yang memiliki pengaruh dan kepentingan dikatakan sebagai stakeholder primer dan harus dilibatkan penuh dalam tahapan-tahapan kegiatan.
Dapat dimaknai bahwa Stakeholder primer atau utama adalah stakeholder yang yang harus ada dalam suatu bentuk kegiatan atau program, sebab kehadirannya merupakan penentu keberlangsugan suatu program atau kegaitan pembangunan termasuk pariwisata. Stakeholder primer harus terlibat secara penuh dalam suatu program atau kegiatan. Sehingga apa yang menjadi tujuan dan harapan suatu kegiatan atau program dapat terwujud.

Stakeholder primer atau utama dalam pengembangan destinasi wisata adalah masyarakat yang tinggal di lokasi destinasi wisata atau masyarakat di sekitar destinasi wisata. Masyarakat sebagai pelaku utama dalam pengembagan destinasi wisata, tentunya penting untuk mendapatkan pembekalan dan sosialisasi dari instansi terkait dalam ranka mempersiapkan sumberdaya pengelolaan dan penegembagan destinasi wisata. Masyarakat sebagai pelaku uatama pengembagan destinasi wisata, harus lebih kreatif dan inovatif dalam pengemabgan destinasi wisata.

Berdasarkan beberapa hasil penelitian bahwa, masayarakat sebagai pelaku utama pengambagan destinasi wisata telah berperan aktif sesuai dengan tugasnya. Sisi negatifnya adalah, tidak sedikit dari masyarakat yang melakukan pengelolaan terhadap pengembagan destinasi wisata tidak memiliki pengetahuan yang memadai dalam hal pengembagan dan pengelolaan destinasi wisata. Hal ini dibuktikan dengan adanya 
destinasi wsiata yang dikelola dan diciptakan langsung oleh masayarakat nyaris tidak dikunjungi oleh wisatawan. Fakta tersebut dapat kita jumpai di berbagai destinasi wisata diberbagai daerah.

Solusi dari permasalah tersebut adalah, perlu adanya dukungan pemerintah terkait dalam hal pendampingan terhadap masyarakat yang ada dan atau tinggal di sekitaran destinasi wisata untuk memperispakan sumberdaya masyarakat dalam pengelolaan dan pengembangan potensi destinasi wisata. Demikian juga perlu adanya pelibatan akademisi dalam hal penelitian terkait uji kelayakan dan juga memberikan pembekalan kepada masyarakat terkait pengembangan kepariwisataan.

Masyarakat sebagai stakeholder utama dapat dikelompokkan menjadi 3 bagian, yaitu: a) Masyarakat sebagai pembangun fasilitas destinasi wisata, b) Masyarakat sebagai pengelola destinasi wisata, dan c) Masyarakat sebagi pengguna atau pengabil manfaat terhadap destinasi wisata. Ketiga kelompok masyarakat tersebut harus memiliki pehaman dan pengetahuan terkait pembangunan, pengelolaan dan pemanfaatan destinasi wisata dengan benar.

2. Stakeholder Kunci

Stakeholder kunci, yakni yang berpengaruh kuat dan penting terkait dengan masalah, kebutuhan dan perhatian terhadap kelancaran kegiatan. Stakeholder turut memainkan peranan penting dalam proses pembuatan kebijakan (Bramana, 2018).
Stakeholder kunci adalah mereka yang memiliki kewenangan legal dalam hal pengambilan keputusan (Handayani and Warsono, 2017). Dalam kata lain bahwa Stakeholder kunci memiliki peran penting setelah stakeholder utama dalam pelaksanaan suatu program atau kegiatan.

Stakeholder kunci pada sector pariwisata adalah pemerintah daerah terkait, dalam hal ini Dinas Pariwisata dan Pemerintah Daerah atau Pusat bidang pariwisata. Pemerintah memiliki wewenag legislative dan eksekutif dalam penentuan kebijakan dalam penegmbangan dan keberlanjutan dunia pariwisata. Juga dalam hal penediyaan sumber daya manusia dalam bidang pariwisata.

Berdasarkan uraian tersebut maka dapat diseimpulkan bahwa Pemerintah sebagai stakeholder kunci memiliki tugas sebai berikut; a) sebagai pembuat kebijakan dan program, b) Melaksanakan kegiatan pemberdayaan masyarakat di lokasi destinasi wisata, c) Memberikan bantuan teknis, penyuluhan dan pengembangan lokasi destinasi wisata.

3. Stakeholder Pendukung (Sekunder)

Stakeholders pendukung merupakan stakeholder yang tidak memiliki kepentingan langsung terhadap suatu rencana tetapi memiliki kepedulian yang besar terhadap proses pengembangan. pendukung menjadi fasilitator dalam proses pengembangan suatu kegiatan dan berpengaruh terhadap pengambilan keputusan. stakeholders 
pendukung meliputi para investor atau pihak swasta, LSM, dan peneliti.

Stakeholders pendukung meberikan pengaruh terhadap sikap masyarakat serta pemerintah, dalam kata lain stakeholder pendukung menjadi pemberi pertimbangan dan masukan kepada pemerintah yang menjadi stakeholder kunci dalam mengabil kebijakan atau keputusan legal. Selain itu stakeholder pendukung juga memberikan pengaruh pada sikap masyarakat dalam memberikan pandangan dan langkah yang kongkrit dalam pengembangan destinasi wisata diaman mereka tinggal.

Akademisi sebagai Stakeholders pendukung perlu dan penting untuk dilibatkan dalam hal melaksanakan riset yang melahirkan suatau hasil berupa ide/strategi dalam pengembangan destinasi wisata atau menghasilkan produk yang dapat dikelola dan dikembangan untuk menjadi destinasi wisata.

Swasta sebagai stakeholder pendukung memiliki tugas atau peran dalam menrikan sponsor pengambangan destinasi wisata serta membangunfasilitas pendukung dan pelengkap di dsetinasi wisata.

\section{Analisis Peran Stakeholder dalam}

\section{Pengembangan Destinasi Wisata}

Septiano Rio Bramana dalam penelitiannya membagi peran stakeholder yaitu; 1) Modernisator, 2) Katalisator, 3) Dinamisator, 4) Stabilisator, dan 5) Pelopor. (Bramana, 2018). Kelima peran ini melekat pada stakeholder utama, stakeholder kunci dan stakeholder pendukung.

\section{Modernisator}

Pemerintah selaku modernisator bertindak membantu masyarakat menunju medernisasi dalam pembangunan dengan cara meninggalkan gaya hidup tradisional yang sudah tidak sesuai dengan kehidupan modern.

Melalui pembangunan, setiap negara ingin menjadi negara yang kuat, mandiri, diperlakukan sederajat oleh negara- negara lain. Untuk mewujudkan hal tersebut, diperlukan antara lain: penguasan ilmu pengetahuan, kemampuan dan kemahiran manajeral, kemampuan mengolah kekayaan alam yang dimiliki sehingga memiliki nilai tambah yang tinggi, sistem pendidikan nasional yang andal yang menghasilkan sumber daya manusia yang produktif, landasan kehidupan politik yang kukuh dan demokratis, memiliki visi yang jelas tentang masa depan yang di inginkan sehingga berorientasi pada masa depan.

2. Katalisator

Selaku Katalisator, bahwa pemerintah mengendalikan faktor negatif yang cenderung menjadi penghalang sehingga dampaknya dapat diminimalisir, dan dapat mengenali faktor- faktor yang sifatnya mendorong laju pembangunan nasional sehingga mampu menarik manfaat yang sebesar-besarnya.

Pemerintah selaku katalisator mampu mendeteksi sejak dini terkait factorfaktor yang mempengaruhi baik positif maupun negative dalam pembangunan dengan tujuan agar destinsi wisata yang dibangun 
dapat bermanfaat dan menarik perhatian wisatawan sehingga keberlanjutan destinasi wisata dapat dipastikan.

3. Dinamisator

$$
\text { Selaku dinamisator, bahwa }
$$

pemerintah bertindak sebagai pemberi bimbingan dan pengarahan kepada masyarakat yang ditujukan dengan sikap, tindak-tanduk, perilaku, dan cara bekerja yang baik yang dapat di jadikan panutan bagi masyarakat dalam melakukan pembangunan.

4. Stabilisator

$$
\text { Peran stakeholder adalah }
$$

mewujudkan perubahan tidak berubah menjadi suatu gejolak sosial, apalagi yang dapat menjadi ancaman bagi keutuhan nasional serta kesatuan dan persatuan bangsa. Peran tersebut dapat terwujud dengan menggunakan berbagai cara antara lain: kemampuan selektif yang tinggi, proses sosialisasi yang elegan tetapi efektif, melalui pendidikan, pendekatan yang persuasif dan pendekatan yang bertahap namun berkesinambungan.

5. Pelopor

Selaku pelopor, stakeholder harus menjadi panutan (role model) bagi seluruh masyarakat. Pelopor dalam bentuk hal-hal, positif seperti kepeloporan dalam bekerja seprodiktif mungkin, kepeloporan dalam menegakkan keadilan dan kedisiplinan, kepeloporan dalam kepedulian terhadap lingkungan, budaya dan sosial, dan kepeloporan dalam berkorban demi kepentingan negara.

\section{KESIMPULAN}

Penegmbangan pariwisata dan pariwisata berkelanjutan membutuhkan kesadaran serta peran aktif stakeholder. Stakeholder dalam hal ini adalah pemerintah atau unsur lainnya yang memiliki peran eksekutif dan legislatif, masyarakat selaku pengelola dan pengguna merupakan stakeholder kunci dan organisasi masyarakat, swasta serta akademisi selaku stakeholder pendukung tetapi memiliki pengaruh yang sangat besar dalam penentuan dan pengabilan suatu kebijakan juga dapat memberi pengaruh kepda masyarakat.

\section{REFERENSI}

Bramana, S. R. (2018) Peran Stakeholder Dalam Pengembangan Pariwisata Alam Di Kabupaten Jombang. Universitas Airlangga. Available at: http://repository.unair.ac.id/id/ep rint/74660.

Handayani, F. and Warsono, H. (2017) 'Analisis Peran Stakeholders Dalam Pengembangan Objek Wisata Pantai Karang Jahe Di Kabupaten Rembang', Journal of Public Policy and Management UNDIP, 6(1), pp. 1-13.

Hidayah, N. A. et al. (2019) 'Analisis Peran Stakeholder Dalam Pengembangan Wisata Talang Air Peninggalan Kolonial Belanda Di Kelurahan Pajaresuk Kabupaten Pringsewu', Jurnal Administrasi Publik, 7, pp. 55-71. doi: https://doi.org/10.31289/publika. v7i1.2179.

Kristin, R. and Salam, R. (2016) 'Peran Pemerintah Daerah dalam Pengembangan Pariwisata Alam dan Budaya di Kabupaten Tapanuli Utara', JPPUMA: Jurnal Ilmu Pemerintahan dan Sosial Politik 
UMA (Journal of Governance and Political Social UMA), 4(1), pp. 79-

96. doi: https://doi.org/10.31289/jppuma. v4i1.895.

Pemerintah Pusat (2011) Peraturan Pemerintah (PP) tentang Rencana Induk Pembangunan Kepariwisataan Nasional Tahun 2010 2025, Peraturan Pemerintah $(P P)$.

Rahmawati, N., Hilman, Y. A. and Triono, B. (2020) 'Peran Dinas Pariwisata dalam Pengelolaan Wisata Minat Khusus di Kabupaten Ponorogo ', Jurnal Ilmiah Pariwisata Sekolah Tinggi Pariwisata Trisakti, 25(1), pp. 1-9. Available at: http://jurnalpariwisata.stptrisakti. ac.id/index.php/JIP/article/view/1 318. 